2019-12-23

\title{
Building with earth: How we are working to revive an ancient, sustainable building technique
}

\author{
Goodhew, Steve
}

http://hdl.handle.net/10026.1/18365

\subsection{0/20450249.2019.1700077}

Construction Research and Innovation

Informa UK Limited

All content in PEARL is protected by copyright law. Author manuscripts are made available in accordance with publisher policies. Please cite only the published version using the details provided on the item record or document. In the absence of an open licence (e.g. Creative Commons), permissions for further reuse of content should be sought from the publisher or author. 


\title{
Building with earth: How we are working to revive an ancient, sustainable building technique
}

\author{
Steve Goodhew, Jim Carfrae, Karen Hood-Cree, Matthew Fox, Mohamed \\ Boutouil \& Francois Streiff
}

To cite this article: Steve Goodhew, Jim Carfrae, Karen Hood-Cree, Matthew Fox, Mohamed Boutouil \& Francois Streiff (2019) Building with earth: How we are working to revive an ancient, sustainable building technique, Construction Research and Innovation, 10:4, 105-108, DOI: 10.1080/20450249.2019.1700077

To link to this article: https://doi.org/10.1080/20450249.2019.1700077

曲 Published online: 23 Dec 2019.

Submit your article to this journal ๘

Q View related articles ¿

View Crossmark data $־$ 


\title{
Building with earth: How we are working to revive an ancient, sustainable building technique
}

\author{
Steve Goodhew $\mathbb{B}^{*}$, Jim Carfrae, Karen Hood-Cree, Matthew Fox@, Mohamed Boutouil $@$ and Francois Streiff
}

An international research project led by the University of Plymouth is working to update a centuries-old construction technique for a new generation of energy efficient homes. Whilst it used to be common to build houses with subsoil mixed with straw from local fields, traditional "cob" buildings (or "bauge", in French) now fall foul of strict thermal requirements. Here, the CobBauge team explain how, through their research, they believe they have found a way to update the technique to satisfy French and UK building regulations.

Cob buildings date back to over 500 years in Devon and Northern France. In many areas where the subsoil is particularly suitable, they have formed the majority homes, farms and commercial buildings. Originally, cob buildings were constructed from subsoil dug from ground next to the property and mixed with straw from the crops in the surrounding fields. The walling material was mixed with help from animals and built up in layers, often being $700 \mathrm{~mm}$ wide and $1 \mathrm{~m}$ high, which would be manually placed on a stone plinth. Many of these buildings still stand, outlasting contemporaries built with other methods.

The natural resilience of cob is therefore evident, but why re-establish the technique now? A number of drivers push the need for such an updated version of this traditional vernacular form. Firstly, a range of anecdotal sources attest to the comfortable internal environment of these buildings, claiming them to be warm in winter and cool in summer. Secondly, there is the need for all our building materials to be as low energy intensive as we can manage. This is a priority for policy makers, research organisations, regulators and many home buyers. Finally, it increases opportunity for self-builders and mainstream contractors to have a choice of building in areas that have suitable soil, directly from the ground to the wall.

One barrier to its take up is the need to adhere to local and national building regulations. Here, cob is a two-edged-sword because, despite the comfort it bestows, it does not pass thermal building regulations without the walls having to be very thick. However, the other side of the sword comes in the form of the new French thermal regulations RT2018, which not only counts the ability for the material to insulate, but also takes account of the amount of energy used to produce it. The less energy the better, and cob is very 'low-energy' compared to masonry.

\section{The innovation}

Our project, named "CobBauge", aims to capitalise on this opportunity. It is led by the University of Plymouth and funded by the European Union, through Interreg France (Channel) England. Researchers at Plymouth are joined by UK partners Earth Building UK and Ireland (EBUKI) and Hudson Architects, and French partners Ecole Supérieure d'ingénieurs des Travaux de la Construction (ESITC), Parc naturel régional des Marais du Contentin et $\mathrm{du}$ Bessin (PnrMCB) and the University of Caen.

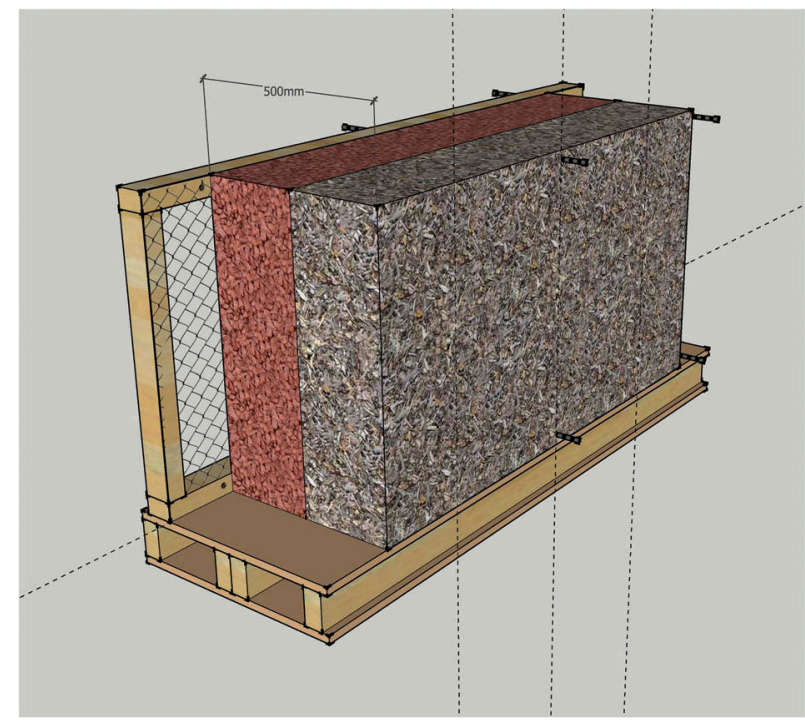

The CobBauge composite wall.

"Professor Steve Goodhew FCIOB is Associate Head of School, School of Art, Design and Architecture, University of Plymouth, and principal CobBauge investigator. Jim Carfrae, Karen Hood-Cree and Matthew Fox are with the University of Plymouth. Mohamed Boutouil is with ESITC, and Francois Strieff is with PnrMCB.

(c) $2019 \mathrm{CIOB}$ 


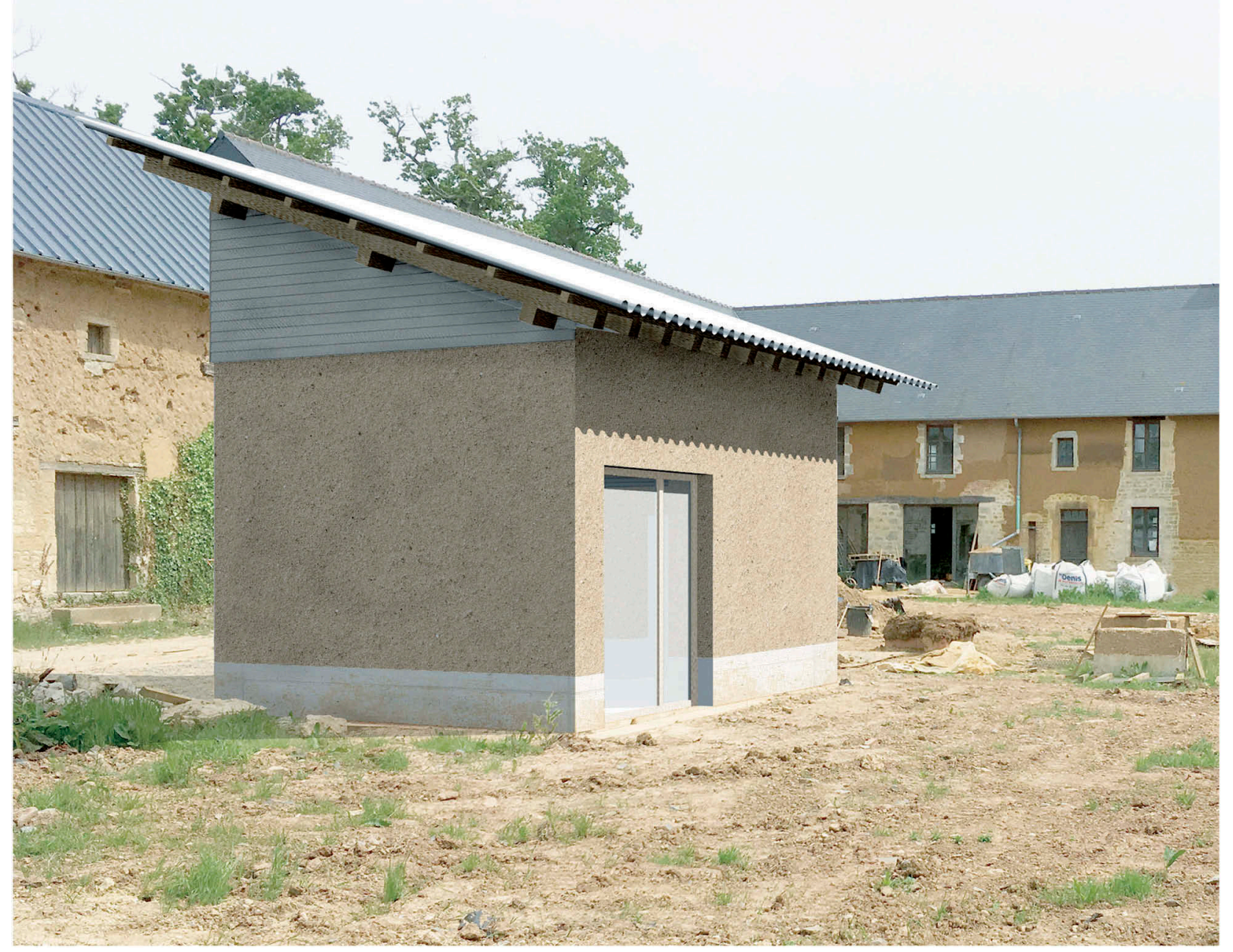

The French prototype building.

We updated the cob technique so that it complies with thermal regulations in both countries. The innovation is a composite wall, with one cob layer insulating the building and the other forming its structural mass, transmitting the various loads of a house through to the foundations. We arrived at this after two years of work researching and measuring the best combinations of subsoils and fibres to provide the complementary properties of the composite wall.

We intend to build small-scale prototype buildings in Normandy and Plymouth for initial testing, and then we plan to build two more dwellings, one in France and one in England, to be fully monitored whilst occupied.

\section{The research in more detail}

As stated above, anecdotal evidence suggests that buildings constructed from cob provide cool indoor environments in warm climates, and warm internal environments in cool climates. Yet despite this, traditional cob construction currently fails to meet stringent thermal building regulations due to its relatively high thermal conductivity and resultant $\mathrm{U}$-value. This places a significant constraint on the application of cob without additional insulating materials, negating its key benefit as a stand-alone natural material.

In light of the need to reduce energy use by $20 \%$ (as set out in the EU's energy efficiency directive [2012/27/EU]), and to help encourage the application of cob as a 21st century material, the CobBauge team set out to develop a new and innovative low-carbon technology to build cob houses using local soil and agricultural or waste fibres.

The first phase of the project examined different soil types and natural fibres in various densities through rigorous thermal and structural experimentation. Out of this process, an optimised cob material was developed that comprised a composite 


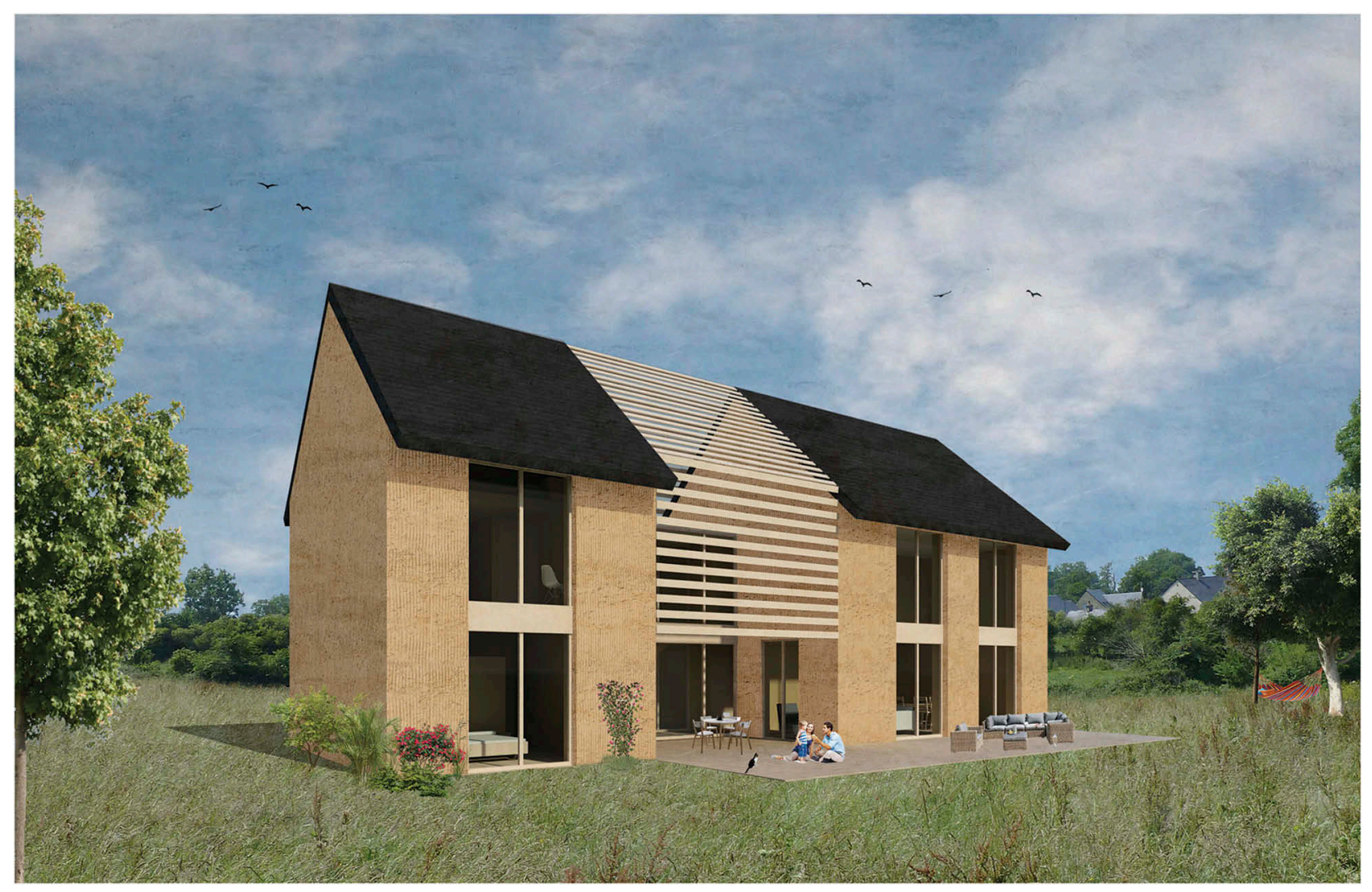

A CAD impression of the French CobBauge pilot building.

construction of a low-density "thermal" cob and a high-density "structural" cob. When used as a composite construction, the two layers bind together to deliver a monolithic material that not only exceeds the building regulations, but also brings a range of additional benefits that will make this new material a viable option for future construction.

Several full-scale wall samples were constructed to determine the most effective way of building with this material. Due to the ease of manipulating these natural materials, a simple shuttered system of construction was developed. It was found that this enabled far quicker construction times compared with traditional cob and other earth based construction materials, helping to complete the building form without needing to wait for the material to dry completely.

Figure 2 shows an image of the prototype building to be constructed in upper Normandy. The team will use this building to test various detail options with a view to optimising the design, leading to a range of standard details that will be offered as part of a training programme for practitioners and professionals. Two further properties will be built, one in France and one in the UK, to allow the project team to monitor the performance of occupied buildings in the construction phase. Currently, the locations for the two properties are likely to be on the BrittanyNormandy border and in East Anglia.

\section{If it worked before ...}

There are many examples of cob buildings from the Tudor period (1485-1602) in Devon, including properties in villages such as Coleford, Silverton and Cheriton Bishop. As with many properties made from natural materials, cob buildings can, with appropriate upkeep, last for centuries.

Traditional cob buildings were normally limited to two or three storeys, which is appropriate for most modern dwellings. A limitation of the technique is that that their best performance comes from a building season running from March to late October. This can be extended by using tented site environments or by using stabilisers such as lime, but this increases costs and removes some of the benefits of such a low embodied energy solution. One of the elements of the innovation of CobBauge is the use of perforated formwork that speeds up the process of construction whilst allowing the walls to breathe, and therefore to dry out quickly.

We believe cob buildings offer a good solution to challenges we face, and that there is an opportunity to 
learn from our forebears on either side of the Channel. We are not alone. In October, CobBauge won the sustainability category of the RegioStars awards in Brussels. Organised by the European Commission, RegioStars recognises Europe's most innovative regional projects, and CobBauge won over four other shortlisted projects on the night and a total of 30 original entrants to the category.

So, we are proceeding with confidence. In the meantime, we would like to hear from developers or self-builders interested in using the CobBauge technique, with the CobBauge team monitoring the performance of their building. Send enquiries to Hudson Architects in Norfolk (hudsoncobbauge@hudsonarchitects.co.uk) or to the CobBauge lead partner, The University of Plymouth (cobbauge@plymouth.ac.uk).

\section{ORCID}

Steve Goodhew (1) http://orcid.org/0000-0003-1227-217X Matthew Fox (1) http://orcid.org/0000-0002-5578-8064

Mohamed Boutouil (1) http://orcid.org/0000-0002-27528265 